Tjalling C. Koopmans Research Institute Trlligh Aoopmanes

Discussion Paper Series nr: 09-05

\title{
The Importance of Income and Housing Wealth Constraints for Future Residential Mobility
}

Wolter Hassink

Michiel van Leuvensteijn 


\section{Tjalling C. Koopmans Research Institute Utrecht School of Economics \\ Utrecht University}

Janskerkhof 12

3512 BL Utrecht

The Netherlands

telephone $\quad+31302539800$

fax $\quad+31302537373$

website www.koopmansinstitute.uu.nl

The Tjalling C. Koopmans Institute is the research institute and research school of Utrecht School of Economics.

It was founded in 2003, and named after Professor Tjalling C. Koopmans, Dutch-born Nobel Prize laureate in economics of 1975.

In the discussion papers series the Koopmans Institute publishes results of ongoing research for early dissemination of research results, and to enhance discussion with colleagues.

Please send any comments and suggestions on the Koopmans institute, or this series to J.M.vanDort@uu.nl

ontwerp voorblad: WRIK Utrecht

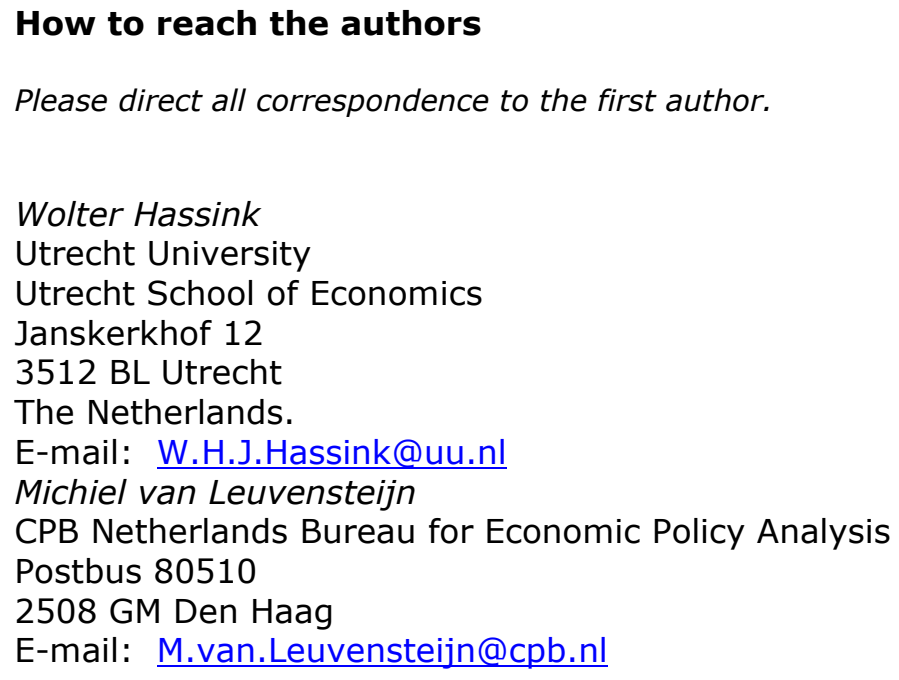

Please direct all correspondence to the first author.

Wolter Hassink

Utrecht University

Utrecht School of Economics

Janskerkhof 12

3512 BL Utrecht

The Netherlands.

E-mail: W.H.J.Hassink@uu.nl

Michiel van Leuvensteijn

CPB Netherlands Bureau for Economic Policy Analysis

Postbus 80510

2508 GM Den Haag

E-mail: M.van.Leuvensteijn@cpb.nl

This paper can be downloaded at: http://www.koopmansinstitute.uu.nl 
Utrecht School of Economics

Tjalling C. Koopmans Research Institute

Discussion Paper Series 09-05

\title{
The Importance of Income and Housing Wealth Constraints for Future Residential Mobility
}

\author{
Wolter Hassink ${ }^{a}$ \\ Michiel van Leuvensteijn ${ }^{\mathrm{b}}$
}

${ }^{a}$ Utrecht School of Economics Utrecht University

${ }^{\mathrm{b}}$ Netherlands Bureau for Economic Policy Analysis

April 2009

\begin{abstract}
We investigate the size of the mark-up on the lending rate for endowment mortgages, due to expected prepayment by the borrower. For this type of mortgage, prepayment is mostly the result of mobility in the housing market. We control for the risk of default by using a unique data set of Dutch borrowers insured against default. The estimates indicate that households with a higher liquidity constraint are less likely to prepay, as they have a lower mark-up on the lending rate. In contrast, the collateral constraint has a very limited influence on the mark-up. We explain this result as follows. Usually, income constraints are generated at the household level, whereas constraints on housing wealth pertain to the regional level. Hence, income changes may improve the relative position of households in the housing market, but an increase in homeowners' housing wealth does not improve their relative position in the housing market.
\end{abstract}

Keywords: Mortgage market; Prepayment, Lending rate; Liquidity constraint; Collateral constraint; Residential mobility

JEL classification: D40, D80, E43

\section{Acknowledgements}

We wish to express our gratitude to the National Mortgage Guarantee (Nationale Hypotheek Garantie) in Zoetermeer, in particular Karel Schiffer and Hans Mersmann, for providing us access to their data as well as for their hospitality. We have benefited very much from stimulating discussions with Clemens Kool. We are grateful to Martijn Dröes and Wouter Vermeulen for their comments on a previous draft 


\section{Introduction}

This paper shows that lenders' expectations about prepayment in home mortgage lending may have significant consequences for a borrower's cost of housing. We concentrate on prepayment as a result of residential mobility. One of the main consequences of moving residence is that it terminates the current mortgage contract prior to maturity. As a result, the mortgage lender may be left with additional costs of prepayment. Its funding of the current mortgage loan no longer matches the incoming flow of interest payments, necessitating a potentially costly reinvestment of its portfolio while the interest rate for reinvestment may have decreased (see Dattatreya and Fabozzi (2001)). The mortgage lender would pass the actual costs of prepayment on to the household, and the household would include the costs of prepayment in its decision to move. However, in the Dutch mortgage market, which is investigated in this paper, the mortgage lender, instead of the borrower, incurs the costs of prepayment associated with unexpected residential mobility at the moment of prepayment (see Mercer, Oliver and Wyman (2006)). ${ }^{1}$

Lenders in the mortgage market are forward looking. When setting the lending rate, they include considerations about possible prepayment of the household. Hence, Dutch mortgage lenders transfer the expected costs of prepayment to the mortgage borrower when writing up the mortgage contract. It leads to a mark-up on the lending rate, which depends on the expected residential mobility of the mortgage borrower prior to maturity. A higher expected mobility of the household gives a higher probability of prepayment and, hence, a higher mark-up on the lending rate. Its drawback is that the lender's expectations formation about residential mobility is based on imperfect information about the individual household. It leads to a distortion of the mark-up on the lending rate, so that pricing in the mortgage market does not fully reflect individual prepayment. Consequently, the user's cost of housing may not be at the optimal level, rendering the housing market less flexible.

This paper considers explicitly the lender's perspective of prepayment. More specifically, its aim is to quantify the size of the mark-up on the lending rate, as a result of the lenders' expectation about prepayment due to mobility in the housing market. Residential changes may be affected by the borrower's loan-to-income ratio (liquidity constraint) as well as his loan-to-value ratio (collateral constraint). However, both constraints may change during the term of the mortgage contract. The main unresolved question in the literature is whether households are more likely to move (and thus to prepay) in case of a relaxation of the liquidity

\footnotetext{
${ }^{1}$ In the UK, Spain, and Portugal, borrowers incur the costs of prepayment due to residential moves upon prepayment. This is not allowed in e.g. Denmark, France, Germany, Italy, and the Netherlands.
} 
constraint due to a growth in household income or in case of a less stringent collateral constraint due to an increase in housing wealth (as a result of rising house prices).

The paper is related to two important strands of literature. First, it is related to studies that investigate the effect of (financial) constraints in the mortgage market on residential mobility. Cameron and Muellbauer (1998) recognize that ceilings on loan-to-income ratios could hamper migration between regions in the UK. Henley (1998) and Chan (2001) show that a low or negative housing equity impedes moving. Böheim and Taylor (2002) and Van Ommeren and Van Leuvensteijn (2005) show that changes in income and (regional) house prices may increase residential mobility. Second, this paper is related to studies of the effect of financial constraints on the probability of prepayment. Ortalo-Magné and Rady (2006) show that credit constraints and income shocks are important factors behind the decision to prepay. Archer et al. (1996), Alink (2002) and Charlier and Van Bussel (2003) show that prepayment is largely driven by collateral and liquidity constraints. The novelty of this paper is that it gives an estimate of the costs to lenders associated with expected residential mobility. It provides the mark-up on the lending rate a household has to pay, when it is expected to be relatively more mobile in the housing market.

Although many studies have been published on the determinants of the mortgage lending rate individual households have to pay (see for instance Hendershott and Van Order (1987), Duca and Rosenthal (1994), Nothaft and Perry (2002), Archer et al. (2003), GaryBobo and Larribeau (2004)), there are no studies that estimate the mark-up to (the costs of) prepayment due to unforeseen residential mobility. The main identification problem is that the mark-up on the lending rate may be due to both the risk of prepayment and the risk of default. An additional complication is that a higher risk of default reduces the risk of prepayment. Usually, both risks cannot be disentangled empirically due to a lack of suitable instrumental variables. This paper applies a unique setting in which lenders do not face the risk of default as they are insured against this event. We were able to control for default risk of households by using administrative information of mortgagors who were covered for this risk by the Dutch National Mortgage Guarantee (NMG). All costs associated with default, such as delayed interest payments as well as the costs of auction are reimbursed by this organisation (NMG (2004)). Hence, mortgage lenders only face the costs of prepayment.

The remainder of this paper is structured as follows. Section 2 gives a description of the relevant Dutch institutions. Section 3 gives a theoretical model and Section 4 the empirical model. Section 5 describes the data. Section 6 provides the estimates. Section 7 concludes. 


\section{Dutch institutional setting}

In the Netherlands, there are various types of mortgages (annuity mortgages, escrow mortgages, endowment mortgages, repayment mortgages, and a type for which there is no repayment). For all of these mortgages, the interest payments are fully tax deductible, rendering it unprofitable to prepay the mortgage. ${ }^{2}$ In this paper, we focus on endowment mortgages, which was the most commonly used in our period of investigation. ${ }^{3}$ Specific for this type of mortgage is that households build up financial capital during the lending term, by paying a monthly fixed amount of money. ${ }^{4}$ In addition, households receive an interest on their financial capital that is equal to the mortgage lending rate. The accumulated financial capital equals the mortgage loan at maturity, so that borrowers can repay the full mortgage loan at the end of the lending term.

Usually, the lending term of an endowment mortgage is a period of 25 or 30 years. Within this term, the lending rate is fixed for a specified period at the discretion of the borrower. Frequently used fixation periods for endowment mortgages are 1, 2, 5, 10, 15 or 20 years. When a period of fixed lending rate ends and the mortgage loan has not yet been repaid, a new lending rate is set for a specific period. Typically, the government bond rate is used as a benchmark for mortgage lending rates.

Dutch households may prepay (part of) the loan before the end of the fixed lending rate term. Basically, mortgage lenders can respond to prepayment in two different ways. First, they can respond ex post by charging a penalty for actual prepayment. Second, they can anticipate ex ante by setting a mark-up on the lending rate that depends on the expected (costs of) prepayment. The penalty ex post is more efficient, as it depends on actual behaviour of an individual borrower. However, a penalty implies switching costs for the borrower, rendering the lender less attractive than its competitors. All in all, a mortgage lender faces a trade-off between the ex post prepayment penalty and the ex ante mark-up on the lending rate.

Most lenders opt for a prepayment penalty. The prepayment penalty then is calculated as the difference between the discounted flow of remaining interest payments for the remaining period of the fixed lending rate and the discounted flow of interest payments at the current lending rate. Hence, households will be less inclined to prepay when the remaining

\footnotetext{
${ }^{2}$ Tax savings can be very substantial. In the highest income tax bracked, 52 percent of the interest payment of mortgage loans are tax deductible. Or as Girouard et al. (2006) put it "Dutch households have strong incentives to maintain mortgage at high levels given the extremely favourable tax treatment of debt-financed owneroccupied housing."

${ }^{3}$ About 65 percent of the Dutch mortgages transactions involved an endowment mortgage.

${ }^{4}$ Part of this transfer is used to pay for the payment of an insurance premium. The lender requires a life insurance on part of the financial capital that has not been build up yet (the difference between the mortgage loan and the financial capital).
} 
term of fixed lending rate is large or when there is a minor difference between their mortgage lending rate and the current market lending rate.

Basically, there are five clauses that exempt borrowers from paying a prepayment penalty. 1) Destruction of the house. 2) Death of the borrower. 3) Adjustment of the lending rate to the current market rate at the end of fixed lending rate term. 4) An annual prepayment of less than 10 to 20 percent of the original loan (the actual threshold may differ across lenders). 5) Selling of the home that serves as collateral due to the borrower moving residence. Hence, for each of these events, the mortgage lender incurs all costs of prepayment. $^{5}$

We claim that it is not likely that there is prepayment for other reasons than residential change. In other words, in our empirical analysis the fifth clause is the main reason of prepayment for the endowment mortgages we investigate. Home destruction can be ruled out, as it is a random and rare occasion (clause 1). Survival hazards of the household do not need to be accounted for, as we control for the age of the (head of the) household in the regression equation (clause 2). Furthermore, we focus on a set of mortgage contracts with a fixed lending rate of 10 years, which do not allow households to reset the interest rate (clause 3). It is very costly for a household to prepay an endowment mortgage within the first 15 years of the contract (clause 4), since the household will be not by exempted from tax payments if they prepay during this period for reasons other than residential change. Finally, the benefits of prepaying endowment mortgages are minor, as lower interest payments result in higher endowment payments to compensate for the lower discount rate. Overall, within the context of this study, residential change is the most likely reason for prepayment and therefore the lender's greatest concern when setting the mortgage interest rate.

\section{Theory}

In the literature on optimal residential mobility, residential moves are assumed to be the result of long-term planning based on evaluations of permanent income, expected household composition, wealth formation and aging (see e.g. Amundsen (1985); Englund, (1985); Hardman and Ioannides (1995)). Given the household's income, and the prices of housing services and of other goods, the household's objective is to determine the optimal housing duration and the optimal consumption of housing services (and other goods). The price of housing services depends on the mortgage's interest rate, $r_{0}$, agreed upon at $t=0$. In

\footnotetext{
${ }^{5}$ During the period 1996-2001 it was not common to keep the mortgage when moving.
} 
this section, we abstract both from demographic characteristics of the household (such as age) and from observed characteristics of the home.

Residential mobility can be described by a housing duration variable $D$, which is a function of the vector $Z_{t}$ :

$$
D=\theta\left(Z_{t}\right)
$$

with $Z_{t}=\left(L_{t} / Y_{t}, L_{t} / H_{t}, Y_{t}\right)$, which is a vector that contains the loan-to-income ratio $(L / Y)$, the loan-to-value ratio $(L / H)$, and the gross household income $(Y)$. $L$ denotes the size of the mortgage loan and $H$ indicates the house value. Usually, Dutch mortgage lenders apply the criterion that the maximum of $L / Y$ is 4.5 and that the maximum of $L / H$ is $1.25 .{ }^{6}$ Home duration $D$ depends positively on $(L / Y)$ and $(L / H)$. For a household that has one of these ratios close to the maximum, it is harder to find another house within the same regional housing market that has better characteristics and for which both constraints are still below the maximum. ${ }^{7}$ Generally, borrowers can be constrained by a high $L / Y$ and $L / H$ at $t=0$. Both constraints may be relaxed over the period of the loan, because of either an increase in household income $(Y)$ or an increase in the value of the collateral $(H)$. The third argument in equation (1) is $Y$. An increase in income raises the likelihood to move and limits the housing duration (ceteris paribus on the other ratios). Higher-income households tend be further in their residential career and are therefore less likely to move.

We consider the costs of prepayment to the lender due to unforeseen residential mobility of the borrower at $t=0 .{ }^{8}$ At $t=\theta(Z)$ there will be prepayment due to a residential chance and at $t=T$ the term of fixed lending rate expires. In addition, the lending rate in the market upon prepayment is $r_{\theta(Z)}$. The lender incurs a loss when $r_{\theta\left(Z_{t}\right)}<r_{0}$. This loss is taken over the remaining term of lending between $t=\theta(Z)$ and $t=T$. The mark-up on the lending rate at $t=0$ is the discounted loss over the period $\left[\theta\left(Z_{t}\right), T\right]$ as expressed in

$$
\operatorname{Markup}_{0}=\int_{\theta\left(Z_{t}\right)}^{T} \rho^{t} *\left[r_{0}-r_{\theta\left(Z_{t}\right)}\right] d t
$$

\footnotetext{
${ }^{6}$ Compared to other European countries, homeowners in the Netherlands can borrow against relatively high loan-to-value ratios. The maximum loan-to-value ratio for Dutch residences amounts to 125 percent of the property value. In France, the UK and Spain the maximum loan-to-value ratio ranges between 100 and 110 percent and in Germany and Italy it is around 90 percent (see Mercer, Oliver and Wyman (2003)).

${ }^{7}$ In addition, the buyer of a house has to pay an ad-valorem buyer transaction tax in the Netherlands (Van Ommeren and Van Leuvensteijn (2005)).

${ }^{8}$ Basically, this loss to the lender is equal to the penalty a household has to pay in case of the prepayment being higher than 10-20 percent of the loan (the exact value differs between borrowers). See Section 2.
} 
where $\rho$ is a discount rate. A longer housing duration gives a shorter period $T-D$, leading to a lower mark-up. Hence, the mark-up on the lending rate depends negatively on $L / Y$ and $L / H$.

The liquidity constraint $(L / Y)$ and the collateral constraint $(L / H)$ may have a different impact on the housing duration $D$. An increase in household income may improve the lending position of the household relative to other households; it thus may lead to an increase in the probability of moving. On the other hand, when all households are hit equally by price development in the housing market, a relaxation of the loan-to-value ratio does not automatically imply that the household is able to improve their home quality by moving.

So far, studies have estimated equation (1) only. Archer et al. (1996) show that households with a high payment-to-income ratio are less likely to prepay their mortgage, although the option to prepay would have a positive return. The advantage of equation (2) is that it gives a quantification of the costs of prepayment in relation to both constraints.

\section{Empirical model}

The purpose of this study is to quantify the effect of $L / Y$ and $L / H$ on the mark-up in the lending rate (equation (2)). The model we estimate is:

$$
r_{i j t}-r_{i j t}^{b}=\alpha_{i}+\tau_{t}+\beta_{1} \log \left(L_{i j t} / Y_{i j t}\right)+\beta_{2} \log \left(L_{i j t} / H_{i j t}\right)+\beta_{3} \log \left(Y_{i j t}\right)+\gamma^{\prime} X_{i j t}+\varepsilon_{i j t}
$$

where subscript $i$ refers to the $i$-th lender, subscript $j$ to the $j$-th borrower and subscript $t$ to the $t$-th month. The dependent variable is the difference between the nominal lending rate of the mortgage loan, $r$, and government bonds' interest rate, $r^{b}$ (both measured at the day the mortgage deed is formally signed). In this respect, the bond has the same term as the mortgage loan (in our analysis a period of 10 years). We will refer to the difference $r-r^{b}$ as the spread. We include a dummy variable for the $i$-th lender, $\alpha_{i}$, as well as a dummy for the $t$ th month $\left(\tau_{t}\right) . X$ is a vector of observed household-specific effects, and the vector $\gamma$ contains the corresponding parameters. $\varepsilon$ is a stochastic error term which is identically and independently distributed.

The vector $X$ contains the remaining control variables: five dummy variables for the age class of the household, and three dummy variables for apartment, overdue maintenance of the home and newly-built homes. These variables may capture one of the other reasons for prepayment: destruction of the home. The effect of age can be twofold. First, it is included to 
control for the lower survival rate of older people, so that they have a higher probability to prepay. Second, older people may have a longer housing duration, so that they have a lower probability to prepay. Alink (2002) finds that older people have lower probability to prepay. Likewise, Charlier and Van Bussel (2003) find that older borrowers have a reduced probability to prepay, although the effect is hardly significant. A dummy for apartment is introduced, because Alink (2002) finds a positive effect of apartment on prepayment for fiveyear fixed interest rates mortgages with interest-only. Charlier and Van Bussel (2003) find a positive effect of apartment on prepayment risk for endowment mortgages. A home with overdue maintenance (that is determined by the borrower) has an increased risk to deteriorate with a concomitant loss in value. We therefore expect houses with back repair to have a higher interest rate. A dummy for new home is used to pick up the fact that new homes have a lower lending rate than existing homes. ${ }^{9}$

\section{Data}

Basically, the mortgage transactions we analyse are free of default risk. The data were provided by the NMG. This guarantee was set up by the Dutch government in the mid-1990s in order to stimulate homeownership for the lower segment of the Dutch housing market. In the Netherlands, buyers of a home may opt to insure their risk of default with the NMG. For a small insurance premium ( 0.15 percent of the mortgage loan) to be paid at the date of the mortgage transaction, they receive a discount on the lending rate in return $(0.2-0.5$ percentage points $)^{10}$, since they nullify the risk of default to the mortgage provider. Of course, given that borrowers with higher loan-to-value ratio's still have a higher probability to default and a higher prepayment risk. This part of the default risk is still identified in the data as it coincides with prepayment. Thus, part of the risks is covered by the NMG, but the prepayment risk for the lender remains. The criteria of eligibility for this guarantee are not particularly stringent. ${ }^{11}$ First, the value of the mortgage has to be below 420 thousand guilders in 2000 and 2001. ${ }^{12}$ Thus, our analysis concentrates on the lower segment of the Dutch

\footnotetext{
${ }^{9}$ In the Netherlands, it is common practice to have a discount on the interest rate on newly-built homes that were constructed in the same building project (and purchased by different homeowners). Fixed costs are lower to the lender so that they can ask for a lower lending rate. These reductions can be substantial, around 10 base points.

${ }^{10}$ The size of the discount is positively related to the loan-to-value ratio, so that households with a higher loanto-value ratio receive a higher discount of the lending rate. So ex-ante, all borrowers receive the same interest rate independent from their loan-to-value ratio.

${ }^{11}$ These criteria are more stringent than the criteria for mortgages usually set by lenders. The maximum mortgage loan depends on the gross income of both the head of the household and the partner. Furthermore it depends on the house value (NMG (2004)).

121 Dutch Guilder (Gld.) is worth 0.45 Euro.
} 
mortgage market. Furthermore, 12 percent of the maximum value of the loan is reserved for transaction costs like transfer taxes and intermediation and notary fees. ${ }^{13}$ The advantage of this data set is that the information is free from measurement error, as it was used by the NMG to assess the eligibility of individual households.

We concentrated on endowment mortgages with a fixed lending rate of 10 years at the start of the contract; we selected mortgages that were not used to refinance the home. ${ }^{14}$ Furthermore, all lenders were required to be experienced in judging prepayment risk through transactions in this segment on a regular basis. We selected a subset of lenders that had mortgage loans in this segment in all months of the period of investigation (January 1996 October 2001). We excluded 58 lenders and retained information on 66,698 borrowers from 14 lenders.

\section{Table 1 about here}

Table 1 gives the descriptive statistics of the variables that we will use in the analysis. The average lending rate is 6.03 percent. The spread (the difference between the lending rate and the 10 -year bond rate) is on average 0.80 percent. Borrowers are concentrated in the younger age cohorts, with about 20 percent being younger than 25 years, and about 70 percent being between 25 and 40 years of age. 17 percent of the mortgages are used for newly-built property and 19 percent for apartments. About 4 percent are used for overdue maintenance. The household's gross annual income is about 76 thousand guilders. The value of the loan is on average 240 thousand guilders, and the house value 237 thousand guilders. For most of the mortgages, the loan-to-value ratio exceeds 1 . The dummies of this ratio indicate that it is skewed to the right. The loan-to-income ratio, the other financial constraint, is skewed to the right also. For about 22 percent of the mortgages, the loan-to-income ratio exceeds 3.75. Thus, a large fraction of the households borrows close to its maximum loan capacity.

\section{Table 2 about here}

\footnotetext{
${ }^{13}$ In 2002, the NMG required that the maximum share of gross income spent on housing is 28-37 percent.

${ }^{14}$ The advantage of this selection is that the mortgages are homogenous in this respect. A period of 10 years is the most commonly used in our data set. Households that expect to prepay at the end of the fixed lending rate period will select themselves into a shorter term.
} 


\section{Estimates}

\subsection{All lenders}

This sub-section discusses the estimation results of equation (3) presented in Table 2. It gives the estimated effect of the liquidity constraint and the collateral constraint on the spread, while controlling (among others) for household income. We also consider a more flexible specification of equation (3), in which the collateral and liquidity ratios are replaced by dummy variables. For all estimated parameters we report heteroskedasticity-adjusted robust standard errors, which are clustered towards the lender. ${ }^{15}$

In the first specification, the estimated coefficient on the (log of the) loan-to-value ratio is statistically insignificant, whereas the (log of the) loan-to-income ratio has an estimated coefficient of -0.126 . An increase of this ratio by 10 percent decreases the spread by 1.26 basispoints. ${ }^{16}$ It implies that households that are seriously constrained with respect to liquidity are less likely to prepay. Consequently, they have to pay a lower mark-up on the lending rate. In contrast, collateral constraints do not influence the mark-up on the lending rate. Interestingly, these estimates make it possible to consider the effect of loan and income on the spread. We can reformulate equation (3) as:

$$
r_{i j t}-r_{i j t}^{b}=\alpha_{i}+\tau_{t}+\eta_{1} \log \left(L_{i j t}\right)+\eta_{2} \log \left(H_{i j t}\right)+\eta_{3} \log \left(Y_{i j t}\right)+\gamma^{\prime} X_{i j t}+\varepsilon_{i j t}
$$

where $\eta_{1}=\beta_{1}+\beta_{2}, \eta_{2}=-\beta_{2}$, and $\eta_{3}=\beta_{3}-\beta_{1}$. The estimated coefficients on the value of the loan, the value of the home, and the household income (all in logarithm) are $\hat{\eta}_{1}=-0.115(\mathrm{t}-$ value: -10.70$), \hat{\eta}_{2}=-0.011$ (t-value: -0.82 ), and $\hat{\eta}_{3}=0.082$ (t-value: 4.05$)$, respectively. The other explanatory variables remain unaffected.

Next, we consider a more flexible specification with the eight dummy variables for the loan-to-value ratio and five dummy variables for the loan-to-income ratio (see the second column of Table 2). The loan-to-value dummies are jointly significant (F-statistic: 5.76; critical value: 5.65 ). However, only the dummy variables in the range $0.95-1.10$ are individually significantly different from the reference category (loan-to-value ratio $>1.10$ ). With respect to the reference category, the spread is 0.9 basispoints (loan-to-value ratio: 0.95 - 1.00) and 1.8 basispoints (loan-to-value ratio: 1.00 - 1.05) lower. It implies that borrowers in the reference category have a higher spread than the borrowers in the categories with lower loan-to-value rates.

\footnotetext{
${ }^{15}$ The variation of the lender dummies suggests that lenders have market power as a result of imperfect information of borrowers.

${ }^{16} 100$ base points equals 1 percentage point.
} 
The estimated coefficients on the dummy variables for loan-to-income ratio are jointly statistically significant at the 5 percent level (F-statistic is 83.9). Their economic significance is quite substantial. There is a negative effect of the loan-to-income ratio on the spread. At maximum (for the loan-to-value ratio below 2.75), the spread is 8.7 basispoints higher than the reference category (which is the loan-to-income ratio $>3.75$ ).

With respect to the other control variables, we find that age has no influence on the spread. ${ }^{17}$ Newly-built homes have a spread that is 1.2 basispoints smaller than that of other homes. Furthermore, the fact that a household has purchased an apartment does not affect the mortgage interest rate, partly because we have corrected for both borrower age and house value. This is in line with other empirical studies, which show that the fact that a home is an apartment does not affect prepayment risk (see for instance Alink (2002)). When maintenance of the home is overdue (that is determined by the borrower), the spread increased by 1.2 basispoints. Finally, we find that household income reduces the interest rate mark-up significantly. A 1 percent higher income reduces the interest rate with 4.4 basispoints (ceteris paribus on the loan-to-income ratio). ${ }^{18}$ High-income households have a longer housing duration and are thus less likely to prepay (Abrahams (1997)).

\subsection{Robustness checks}

This sub-section considers two robustness checks. First, from the fourteen lenders, we selected the six lenders with the largest market share in this specific segment of the mortgage market. It reduces the sample by 27 percent to 49,967 observations. The first two columns of Table 3 present the estimates. They give the same impression as the overall sample. The first column of this table shows that the loan-to-value ratio has no significant effect on the spread, whereas the loan-to-income ratio has about the same effect as in Table 2. The second column shows that both the dummies for loan-to-value $(\mathrm{F}(49951,8)=11.8)$ and the dummies for the loan-to-income ratio $(\mathrm{F}(49951,5)=114.3)$ are jointly significant. For the loan-to-income ratio below 2.75 , the spread is 7.6 basispoints higher than that of the reference category (ratio above 3.75$)$.

\footnotetext{
${ }^{17}$ It is remarkable that age has a negative effect on the dependent variable in the first equation. The second, more flexible specification picks up the effect that starters in the housing market have mortgage loans closer to the maximum constraints of the loan-to-value and the loan-to-income ratio.

${ }^{18}$ However, the marginal effect of the spread with respect to $\log (Y)$ is 0.082 . This positive marginal effect of $\log (Y)$ is a composite of the negative effect of $\log (L / Y)(-0.126$, see Table 2$)$ and the negative effect of $\log (Y)$ $(-0.044$, see Table 2$)$, the latter effect being weaker than the former effect.
} 
As a second robustness check, we included a dummy variable for an increase in the government bond rate during the previous three months. The reason for doing so is that it may take some time between the offer of the mortgage lender (in terms of the size of the lending rate as well as further lending conditions) $(t=0)$ and signing the mortgage deed at the notary $(t=1)$. In case of a fall in the government bond rate during this period, the lending rate in the contract at the notary would be corrected for the decrease of the market lending rate at time $t=1$. However, in case the government bond rate increased in the previous three months, the lending rate in the contract would be equal to the offered lending rate at time $t=0$. As it usually takes about three months between tender and signing of the contract, we created a dummy that would equal one in case of an increase in the government bond rate during the previous three months and would equal zero in all other cases. The estimates in the last two columns of Table 3 show that the introduction of a dummy for a rise in government bond rates makes little difference compared with the outcomes presented in Table 2.

\section{Conclusion}

This paper has considered the consequences of expected residential mobility for the lending rate of home mortgages. Residential mobility reflects the adjustment process between demand and supply in the housing market. Although a flexible housing market is beneficial for society, residential mobility also inflicts costs on the financial sector, due to the early (unexpected) termination of mortgages. In the Netherlands, the lenders incur these concomitant costs at the moment of prepayment, i.e. at the moment when properties are sold. Consequently, lenders want to be compensated for the risk of prepayment, by requiring a higher lending rate in advance, upon the moment of writing the mortgage contract.

In this paper, we have analysed how lenders valuate the importance of liquidity and collateral constraints for residential changes. We were able to address this issue due to the availability of a special data set of the Dutch National Mortgage Guarantee with information on lending rates of endowment mortgages without the risk of default. As for this specific type of mortgage, prepayment is mostly due to moving, we were able to analyse the consequences of the lender's expectation of residential mobility for the size of the mark-up.

The estimates of this paper indicate the liquidity constraint has a negative influence on the mark-up that is associated with prepayment. In other words, households that are more constrained with respect to income have a lower risk of prepayment, so that they have a lower mark-up on the lending rate. Households with a loan-to-income ratio below 2.75 pay a 8.7 
basispoints higher lending rate than households with a loan-to-income ratio above 3.75 . In contrast, the collateral constraint has very little effect on the mark-up.

To the extent that liquidity constraints and collateral restrictions predict future changes in income and wealth, the empirical outcome could have wider implications. Since the variation in prepayment premiums in lending rates is strongly related to moving behavior of households, we can relate the lending rate to lenders' expectations about residential mobility. Residential mobility can be the result of both changes in income and changes in wealth due to increase in the house value. Changes in income are generated mostly at the household level. For example, by changing jobs, households' heads may improve their income. Partners may decide to participate in the labor force or they make quit their job to take care of the children. Changes in income occur more frequently than those in wealth and are therefore considered a higher risk. Furthermore, changes in housing wealth occur mostly at a regional economic level. These can be substantial. In the period 1995-2005, real estate prices in the Netherlands more than doubled (NVM (2006)). Although there are differences across regions, increases in house prices are likely to be very similar at the municipal level. Since most of the residential mobility takes place within a municipality (Everaers and Davis (1993)), changes in housing wealth has no significant effect on the decision to move. This makes sense, because income changes may improve the relative position of households in the housing market. In contrast, overall increases in housing wealth due to a rise in real estate prices do not improve their relative position. All in all, lenders seem to consider a change in income a far greater risk for to residential mobility than a change in the property value. 


\section{References}

Abrahams, S.W., (1997), "The New View on Mortgage Prepayments: Insight from Analysis in at the Loan level," Journal of Fixed Income, 7 (1), 8-21.

Alink, B.J., (2002), Mortgage Prepayment in the Netherlands, PhD-Thesis. Twente University Press.

Amundsen, E., (1985), "Moving Costs and the Microeconomics of Intra-urban Mobility," Regional Science and Urban Economics, 15 (4), 573-583.

Archer, W.R., D.C. Ling and G.A. McGill (1996), "The Effect of Income and Collateral Constraints on Residential Mortgage Terminations," Regional Science and Urban Economics, $26(3,4), 235-261$.

Archer, W.R., D.C. Ling and G.A. McGill (2003), "Household income, Termination Risk and Mortgage Pricing," Journal of Real Estate Finance and Economics, 27 (1), 111-138.

Böheim, R., and M. Taylor (2002), "Tied Down or Room to Move? Investigating the Relationships between Housing Tenure, Employment Status and Residential Mobility in Britain," Scottish Journal of Political Economy, 49 (4), 369-392.

Cameron, G. and J. Muellbauer (1998), "The Housing Market and Regional Commuting and Migration Choices," Scottish Journal of Political Economy, 45 (4), 420-446.

Chan, S. (2001), "Spatial Lock-in: Do Falling House Prices Constrain Residential Mobility?," Journal of Urban Economics, 49 (3), 567-586.

Charlier, E. and A. Van Bussel (2003), "Prepayment Behavior of Dutch Mortgagors: An Empirical Analysis," Real Estate Economics, 31 (2), 165-185.

Dattatreya, R.E. and F.J. Fabozzi (2001), "Risks Associated with Investing in Fixed Income Securities," in: F.J. Fabozzi (eds.), The Handbook of Fixed Income Securities, McGraw-Hill Professional.

Duca, J.V. and S.S. Rosenthal (1994), "Do Mortgage Rates Vary Based on Household Default characteristics? Evidence on Rate Sorting and Credit rationing, Journal of Real estate Finance and Economics, 8 (2), 99-111.

Englund, P. (1985), "Taxation of Capital Gains on Owner-occupied Homes: Accrual Versus Realization,” European Economic Review, 27 (3), 311-334.

Everaers, P.C. and Davies, S. (1993), Verhuizen in Nederland in de jaren tachtig, Maandstatistieken Bouw, Dutch Central Bureau of Statistics, 93/12, 5-26.

Gary-Bobo, R.J. and S. Larribeau (2004), “A Structural Econometric Model of Price Discrimination in the Mortgage Lending Industry," International Journal of Industrial Organization, 22 (1), 101 -134. 
Girouard, N., M. Kennedy, P. van den Noord and C. André (2006), Recent House Price

Developments: the Role of Fundamentals, Economics Department Working Papers No. 475, OECD, Paris.

Hardman A.M. and Y.M. Ioannides, (1995), "Moving Behavior and the Housing Market," Regional Science and Urban Economics, 25 (1), 21-39.

Hendershott, P.H. and R. Van Order (1987), "Pricing Mortgages: An Interpretation of the Models and the Results," Journal of Financial Services Research, 1 (1), 19-55.

Henley, A. (1998), "Residential Mobility, Housing Equity and the Labour Market," Economic Journal, 108 (447), 414-427.

NMG, 2004. Declaratieformulier ('Reimbursement form'), Zoetermeer, The Netherlands.

Nothaft, F.E. and V.G. Perry (2002), Do mortgage rates vary by neighborhood? Implications for loan pricing and redlining. Journal of Housing Economics, 11 (3), 244-265.

Mercer, Oliver and Wyman, 2003, Study on the financial integration of European mortgage markets.

NVM (2006), "Overzicht transactieprijzen woningen bestaande bouw in duizenden euro's". (http:/www.nvm.nl/nvm/getfile?docName=nvm081979)

Ortalo-Magné, F. and S. Rady (2006), "Housing Market Dynamics: On the Contribution of Income Shocks and Credit Constraints," Review of Economic Studies, 73 (2), 459-485.

Van Ommeren, J. and M. Van Leuvensteijn (2005), "New Evidence on the Effect of Transaction Costs on Residential Mobility," Journal of Regional Science, 45 (4), 681-702. 
Table 1 - Descriptive statistics; sample January 1996 - October 2001

\begin{tabular}{|c|c|c|c|c|}
\hline Variable & Mean & $\begin{array}{l}\text { Standard } \\
\text { deviation }\end{array}$ & Minimum & Maximum \\
\hline Lending rate & 6.030 & 0.686 & 3.250 & 10.000 \\
\hline Spread (lending rate -10 -year bond's interest rate) & 0.798 & 0.449 & -1.970 & 4.370 \\
\hline \multicolumn{5}{|l|}{ Dummy variables for Age } \\
\hline Dummy age $\leq 25$ years & 0.185 & 0.388 & 0.000 & 1.000 \\
\hline Dummy $25<$ age $\leq 30$ years & 0.398 & 0.489 & 0.000 & 1.000 \\
\hline Dummy $30<$ age $\leq 35$ years & 0.220 & 0.414 & 0.000 & 1.000 \\
\hline Dummy $35<$ age $\leq 40$ years & 0.104 & 0.306 & 0.000 & 1.000 \\
\hline Dummy $40<$ age $\leq 45$ years & 0.054 & 0.227 & 0.000 & 1.000 \\
\hline Dummy age $>45$ years & 0.039 & 0.193 & 0.000 & 1.000 \\
\hline Dummy newly built property & 0.169 & 0.375 & 0.000 & 1.000 \\
\hline Dummy apartment & 0.192 & 0.394 & 0.000 & 1.000 \\
\hline Dummy overdue maintenance of the home & 0.042 & 0.200 & 0.000 & 1.000 \\
\hline Annual gross income of household (in thousands of guilders) & 76.462 & 110.293 & 11.802 & 282.000 \\
\hline Value of mortgage loan (in thousands of guilders) & 239.606 & 72.626 & 15.950 & 420.000 \\
\hline House value (in thousands of guilders) & 236.691 & 69.041 & 36.000 & 826.391 \\
\hline $\log ($ income of household) & 11.192 & 0.308 & 9.376 & 17.153 \\
\hline $\log$ (value of mortgage loan) & 12.337 & 0.324 & 9.677 & 12.948 \\
\hline Log(house value) & 12.329 & 0.313 & 10.491 & 14.662 \\
\hline Log(loan-to-value) & 0.009 & 0.154 & -2.358 & 0.511 \\
\hline Log(loan-to-income) & 1.145 & 0.226 & -4.439 & 2.142 \\
\hline \multicolumn{5}{|l|}{ Dummy variables for Loan-to-value ratio } \\
\hline Loan-to-value ratio $\leq 0.75$ & 0.057 & 0.232 & 0.000 & 1.000 \\
\hline $0.75<$ Loan-to-value ratio $\leq 0.80$ & 0.023 & 0.149 & 0.000 & 1.000 \\
\hline $0.80<$ Loan-to-value ratio $\leq 0.85$ & 0.031 & 0.175 & 0.000 & 1.000 \\
\hline $0.85<$ Loan-to-value ratio $\leq 0.90$ & 0.039 & 0.193 & 0.000 & 1.000 \\
\hline $0.90<$ Loan-to-value ratio $\leq 0.95$ & 0.047 & 0.213 & 0.000 & 1.000 \\
\hline $0.95<$ Loan-to-value ratio $\leq 1.00$ & 0.084 & 0.278 & 0.000 & 1.000 \\
\hline $1.00<$ Loan-to-value ratio $\leq 1.05$ & 0.110 & 0.313 & 0.000 & 1.000 \\
\hline $1.05<$ Loan-to-value ratio $\leq 1.10$ & 0.369 & 0.482 & 0.000 & 1.000 \\
\hline Loan-to-value ratio $>1.10$ & 0.240 & 0.427 & 0.000 & 1.000 \\
\hline \multicolumn{5}{|l|}{ Dummy variables for Loan-to-income ratio } \\
\hline Loan-to-income ratio $\leq 2.75$ & 0.239 & 0.427 & 0.000 & 1.000 \\
\hline $2.75<$ Loan-to-income ratio $\leq 3.00$ & 0.119 & 0.324 & 0.000 & 1.000 \\
\hline $3.00<$ Loan-to-income ratio $\leq 3.25$ & 0.137 & 0.344 & 0.000 & 1.000 \\
\hline $3.25<$ Loan-to-income ratio $\leq 3.50$ & 0.144 & 0.351 & 0.000 & 1.000 \\
\hline $3.50<$ Loan-to-income ratio $\leq 3.75$ & 0.140 & 0.347 & 0.000 & 1.000 \\
\hline Loan-to-income ratio $>3.75$ & 0.224 & 0.417 & 0.000 & 1.000 \\
\hline $\begin{array}{l}\text { Number of lenders } \\
\text { Number of borrowers }\end{array}$ & $\begin{array}{c}14 \\
66,698\end{array}$ & & & \\
\hline
\end{tabular}


Table 2 - Estimates of equation (3)

\begin{tabular}{|c|c|c|c|c|}
\hline $\begin{array}{l}\text { Dependent variable: Spread } \\
\text { (lending rate }-10 \text { year bond's interest } \\
\text { rate) }\end{array}$ & $\begin{array}{l}\text { Para- } \\
\text { meter }\end{array}$ & t-value & $\begin{array}{l}\text { Para- } \\
\text { meter }\end{array}$ & t-value \\
\hline \multicolumn{5}{|l|}{ Dummy variables for Age a) } \\
\hline Age $\leq 25$ years & -0.008 & -1.08 & -0.004 & -0.27 \\
\hline $25<$ Age $\leq 30$ years & -0.018 & $-2.88 *$ & -0.012 & -1.13 \\
\hline $30<$ Age $\leq 35$ years & -0.011 & -2.05 & -0.007 & -0.73 \\
\hline $35<$ Age $\leq 40$ years & -0.010 & -1.29 & -0.007 & -0.81 \\
\hline $40<$ Age $\leq 45$ years & 0.001 & 0.17 & 0.003 & 0.61 \\
\hline Dummy newly-built property b) & -0.106 & $-5.48 * *$ & -0.012 & $-4.57 * *$ \\
\hline Dummy apartment c) & 0.007 & 1.47 & 0.000002 & 0.00 \\
\hline Dummy overdue maintenance of the home d) & 0.012 & $2.52 *$ & 0.012 & $2.02 *$ \\
\hline Log(income of household) & -0.044 & $-3.02 * *$ & -0.040 & $-3.14 * *$ \\
\hline $\log$ (value of mortgage loan) & - & & - & \\
\hline $\log ($ house value) & - & & - & \\
\hline Log(loan-to-value) & 0.011 & 0.82 & - & \\
\hline Log(loan-to-income) & -0.126 & $-7.34 * *$ & - & \\
\hline \multicolumn{5}{|l|}{ Dummy variables for Loan-to-value ratio e) } \\
\hline Loan-to-value ratio $\leq 0.75$ & \multicolumn{2}{|l|}{-} & -0.009 & -1.03 \\
\hline $0.75<$ Loan-to-value ratio $\leq 0.80$ & \multicolumn{2}{|l|}{-} & -0.005 & -0.57 \\
\hline $0.80<$ Loan-to-value ratio $\leq 0.85$ & \multicolumn{2}{|l|}{-} & 0.007 & 0.93 \\
\hline $0.85<$ Loan-to-value ratio $\leq 0.90$ & \multicolumn{2}{|l|}{-} & -0.006 & -0.68 \\
\hline $0.90<$ Loan-to-value ratio $\leq 0.95$ & \multicolumn{2}{|l|}{-} & -0.009 & -1.08 \\
\hline $0.95<$ Loan-to-value ratio $\leq 1.00$ & \multicolumn{2}{|l|}{-} & -0.009 & $-2.55^{*}$ \\
\hline $1.00<$ Loan-to-value ratio $\leq 1.05$ & \multicolumn{2}{|l|}{-} & -0.018 & $-2.20 *$ \\
\hline $1.05<$ Loan-to-value ratio $\leq 1.10$ & \multicolumn{2}{|l|}{-} & -0.013 & $-2.85^{*}$ \\
\hline \multicolumn{5}{|l|}{ Dummy variables for Loan-to-income ratio f) } \\
\hline Loan-to-income ratio $\leq 2.75$ & \multicolumn{2}{|l|}{-} & 0.087 & $6.48 * *$ \\
\hline $2.75<$ Loan-to-income ratio $\leq 3.00$ & \multicolumn{2}{|l|}{-} & 0.071 & $6.87 * *$ \\
\hline $3.00<$ Loan-to-income ratio $\leq 3.25$ & \multicolumn{2}{|l|}{-} & 0.056 & $5.15^{* *}$ \\
\hline $3.25<$ Loan-to-income ratio $\leq 3.50$ & \multicolumn{2}{|l|}{-} & 0.051 & $5.67 * *$ \\
\hline $3.50<$ Loan-to-income ratio $\leq 3.75$ & \multicolumn{2}{|l|}{-} & 0.035 & $5.69 * *$ \\
\hline Intercept & 1.582 & $9.07 * *$ & 1.341 & $9.30 * *$ \\
\hline Monthly dummies (68 dummies) & \multicolumn{2}{|c|}{$\mathrm{F}(66604,68)=942 * *$} & \multicolumn{2}{|c|}{$\mathrm{F}(66593,68)=941 * *$} \\
\hline Lender dummies (13 dummies) & \multicolumn{2}{|c|}{$\mathrm{F}(66604,13)=303^{* *}$} & \multicolumn{2}{|c|}{$\mathrm{F}(66593,13)=299 * *$} \\
\hline Adjusted $\mathrm{R}^{2}$ & \multicolumn{2}{|c|}{0.514} & \multicolumn{2}{|c|}{0.514} \\
\hline Number of explanatory variables & \multicolumn{2}{|c|}{93} & \multicolumn{2}{|c|}{104} \\
\hline Number of lenders & \multirow{2}{*}{\multicolumn{2}{|c|}{$\begin{array}{c}14 \\
66,698\end{array}$}} & \multirow{2}{*}{\multicolumn{2}{|c|}{$\begin{array}{c}14 \\
66,698\end{array}$}} \\
\hline Number of borrowers & & & & \\
\hline
\end{tabular}

a) Reference group: age over 45 years.

b) Reference group: not newly-built homes.

c) Reference group: remaining homes, other than apartments.

d) Reference group: no back repair of home.

e) Reference group: Loan-to-value ratio $>1.10$

f) Reference group: Loan-to-income ratio $>3.75$

*) Statistically different from zero at $5 \%$ level.

**) Statistically different from zero at $1 \%$ level. 
Table 3 - Estimates of Equation (3), robustness checks

\begin{tabular}{|c|c|c|c|c|c|c|c|c|}
\hline \multirow{2}{*}{$\begin{array}{l}\text { Dependent variable: Spread } \\
\text { (lending rate }-10 \text { year bond's interest rate) }\end{array}$} & \multicolumn{4}{|c|}{ Sample: 6 largest lenders } & \multicolumn{4}{|c|}{ Included a dummy for increasing bond rates } \\
\hline & $\begin{array}{l}\text { Para- } \\
\text { meter }\end{array}$ & t-value & $\begin{array}{l}\text { Para- } \\
\text { meter }\end{array}$ & t-value & $\begin{array}{l}\text { Para- } \\
\text { meter }\end{array}$ & t-value & $\begin{array}{l}\text { Para- } \\
\text { meter }\end{array}$ & t-value \\
\hline $\begin{array}{l}\log \text { (income of household) } \\
\log (\text { value of mortgage loan) } \\
\log (\text { house value }) \\
\log (\text { loan-to-value }) \\
\log (\text { loan-to-income) }\end{array}$ & $\begin{array}{c}-0.045 \\
- \\
- \\
0.012 \\
-0.120\end{array}$ & $\begin{array}{c}-2.25^{* *} \\
\\
0.62 \\
-5.34 * *\end{array}$ & $\begin{array}{c}-0.040 \\
- \\
- \\
- \\
-\end{array}$ & $-2.30 * *$ & $\begin{array}{c}-0.044 \\
- \\
- \\
0.011 \\
-0.126\end{array}$ & $\begin{array}{l}-3.02 * * \\
\\
0.82 \\
-7.34 * *\end{array}$ & $\begin{array}{c}-0.038 \\
- \\
- \\
- \\
-\end{array}$ & $-2.99 * *$ \\
\hline \multicolumn{9}{|l|}{ Dummy variables for Loan-to-value ratio b) } \\
\hline $\begin{array}{l}\text { Loan-to-value ratio } \leq 0.75 \\
0.75<\text { Loan-to-value ratio } \leq 0.80 \\
0.80<\text { Loan-to-value ratio } \leq 0.85 \\
0.85<\text { Loan-to-value ratio } \leq 0.90 \\
0.90<\text { Loan-to-value ratio } \leq 0.95 \\
0.95<\text { Loan-to-value ratio } \leq 1.00 \\
1.00<\text { Loan-to-value ratio } \leq 1.05 \\
1.05<\text { Loan-to-value ratio } \leq 1.10\end{array}$ & $\begin{array}{l}- \\
- \\
- \\
- \\
- \\
- \\
-\end{array}$ & & $\begin{array}{c}-0.002 \\
-0.010 \\
0.015 \\
-0.008 \\
0.001 \\
-0.003 \\
-0.008 \\
-0.007 \\
\end{array}$ & $\begin{array}{c}-0.22 \\
-0.79 \\
2.31^{* *} \\
-1.01 \\
0.21 \\
-0.46 \\
-1.29 \\
-1.83 \\
\end{array}$ & $\begin{array}{l}- \\
- \\
- \\
- \\
- \\
- \\
-\end{array}$ & & $\begin{array}{c}-0.002 \\
-0.001 \\
0.015 \\
-0.004 \\
-0.002 \\
-0.003 \\
-0.008 \\
-0.007 \\
\end{array}$ & $\begin{array}{c}-0.34 \\
-0.12 \\
3.29^{* *} \\
-0.54 \\
-0.49 \\
-0.6 \\
-1.84 \\
-2.61^{* *}\end{array}$ \\
\hline \multicolumn{9}{|l|}{ Dummy variables for Loan-to-income ratio c) } \\
\hline $\begin{array}{l}\text { Loan-to-income ratio } \leq 2.75 \\
2.75<\text { Loan-to-income ratio } \leq 3.00 \\
3.00<\text { Loan-to-income ratio } \leq 3.25 \\
3.25<\text { Loan-to-income ratio } \leq 3.50 \\
3.50<\text { Loan-to-income ratio } \leq 3.75\end{array}$ & $\begin{array}{l}- \\
- \\
- \\
-\end{array}$ & & $\begin{array}{l}0.076 \\
0.064 \\
0.052 \\
0.042 \\
0.030\end{array}$ & $\begin{array}{l}5.15^{* *} \\
6.74^{* *} \\
4.39^{* *} \\
5.16^{* *} \\
7.24 * *\end{array}$ & $\begin{array}{l}- \\
- \\
- \\
- \\
-\end{array}$ & & $\begin{array}{l}0.082 \\
0.067 \\
0.053 \\
0.047 \\
0.032\end{array}$ & $\begin{array}{l}6.83^{* *} \\
8.27 * * \\
5.66^{* *} \\
6.29 * * \\
7.31 * *\end{array}$ \\
\hline $\begin{array}{l}\text { Dummy for period of increasing interest rate } \\
\text { on government bonds }\end{array}$ & & & & & -0.116 & $-2.47 * *$ & -0.118 & $-2.48 * *$ \\
\hline Monthly dummies (68 dummies) & \multicolumn{2}{|c|}{$\begin{array}{c}\mathrm{F}(49873,68)= \\
3383^{* *}\end{array}$} & \multicolumn{2}{|c|}{$\begin{array}{c}\mathrm{F}(49873,68)= \\
3383 * *\end{array}$} & \multicolumn{2}{|c|}{$\mathrm{F}(66603,68)=3300^{* *}$} & \multicolumn{2}{|c|}{$\mathrm{F}(66603,68)=3300^{* *}$} \\
\hline Lender dummies (13 dummies) & \multicolumn{2}{|c|}{$\mathrm{F}(49873,13)=35^{* *}$} & \multicolumn{2}{|c|}{$\mathrm{F}(49873,13)=35^{* *}$} & \multicolumn{2}{|c|}{$\mathrm{F}(66603,13)=62 * *$} & \multicolumn{2}{|c|}{$\mathrm{F}(66603,13)=62 * *$} \\
\hline Adjusted $\mathrm{R}^{2}$ & \multicolumn{2}{|c|}{0.509} & \multicolumn{2}{|c|}{0.509} & \multicolumn{2}{|c|}{0.514} & \multicolumn{2}{|c|}{0.515} \\
\hline $\begin{array}{l}\text { Number of explanatory variables } \\
\text { Number of lenders } \\
\text { Number of borrowers }\end{array}$ & \multicolumn{2}{|c|}{$\begin{array}{c}93 \\
6\end{array}$} & & & \multicolumn{2}{|c|}{$\begin{array}{c}14 \\
66,698\end{array}$} & \multicolumn{2}{|c|}{$\begin{array}{c}14 \\
66,698\end{array}$} \\
\hline
\end{tabular}

a) Estimated coefficients on five age dummies, dummy newly-built property, dummy apartment, dummy overdue maintenance of home and intercept are not reported.

b) Reference group: Loan-to-value ratio $>1.10$.

c) Reference group: Loan-to-income ratio $>3.75$.

**) Statistically different from zero at $1 \%$ level. 